Review

\title{
A review on leadership and leadership development in educational settings
}

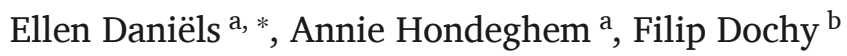 \\ a Public Governance Institute (KU Leuven), Parkstraat 45 Bus 3609, 3000, Leuven, Belgium \\ ${ }^{\mathrm{b}}$ Professional Learning \& Development, Corporate Training and Lifelong Learning (KU Leuven), Dekenstraat 2 Bus 3772, 3000, Leuven, Belgium
}

\section{A R T I C L E INF O}

\section{Keywords:}

School leadership

Leadership development

Leadership for learning

School effectiveness

Leadership

Professional development

\begin{abstract}
A B S T R A C T
Leadership gained a lot of attention during the past decades because of school principals' growing responsibilities and the accountability-driven context they work in. However, reviews providing a general overview of effective school leadership theories and effective professional development are rare. The present review was conducted to summarise the existing literature and discover lacunae in school leadership research in preschools, primary and secondary schools. 75 studies focusing on leadership theories, characteristics of effective school leadership and school leaders' professional development were included and analysed. The present article provides an overview of main leadership theories such as instructional leadership, situational leadership, transformational leadership, distributed leadership and Leadership for Learning. Second, the article focuses on the characteristics of effective school leadership and lastly, the review offers features of effective professional development activities for school principals.
\end{abstract}

\section{Introduction}

Leadership in education often stands in the spotlight, mostly because of growing responsibilities for school principals and the accountability-driven context they work in (Hitt \& Tucker, 2016; Leithwood, 2010; Muijs, 2010). The management of schools is of vital importance to public administration as in OECD-countries (Organisation for Economic Co-operation and Development) on average $13 \%$ of total public expenditures is spent on education (OECD, 2013). The literature emphasizes the impact of leadership on the effectiveness of schools. Principals have a considerable potential in creating learning environments for teachers and students, in enhancing student-learning outcomes through their influence on teachers, and in organisational policy and processes (Hallinger, Bickman, \& Davis, 1996; Hallinger \& Heck, 1998; Hitt \& Tucker, 2016). For decades, leadership in education has been subject to research and resulted in numerous approaches of leadership e.g. instructional leadership, situational leadership, transformational leadership and distributed leadership. Several leadership theories emerged as a critique on previous theories or as an extension or aggregation of existing theories. By summarising the evolvement of school leadership theories, the characteristics of effective leadership and prescriptive elements for the development of school principals' leadership, the study provides directions for future research. Starting from a narrative review approach, an overview of the leadership theories in education will be provided. Then, based on a systematic review of the literature, the paper focuses on effective leadership practices and school principals' leadership development.

\footnotetext{
* Corresponding author.

Email addresses: ellen.daniels@kuleuven.be (E. Daniëls); annie.hondeghem@kuleuven.be (A. Hondeghem); filip.dochy@kuleuven.be (F. Dochy)
} 


\section{Leadership in education}

To provide an overview of leadership theories in education, leadership is first defined. Defining leadership unambiguously is not easy as there is no agreed definition available in the literature. Numerous scholars have researched leadership and most of them stipulate leadership in different ways. The assumption shared by most definitions is that leadership is 'a process of influencing in which an individual exerts intentional influence over others to structure activities and relationships in a group or organisation (Yukl, 2002)'. Bush and Glover (2003) emphasize that Yukl's use of an individual must be seen in a wider perspective. In education, leadership may be exercised by teams as well as individuals (Bush \& Glover, 2003). What emerges in various definitions of leadership in education is the particular focus on the core process and goals of education: teaching and learning and student achievement (see f.i. Bush \& Glover, 2003; Devos \& Bouckenooghe, 2009; Grissom \& Loeb, 2011).Though, leadership studies in education have often been criticised for solely focusing on cognitive student outcomes (Devos \& Bouckenooghe, 2009). Bush \& Glover propose a definition of school leadership and recap school leadership as follows:

Leadership can be understood as a process of influence based on clear values and beliefs and leading to a 'vision' for the school. The vision is articulated by leaders who seek to gain the commitment of staff and stakeholders to the dream of a better future for the school, its students and stakeholders. (Bush \& Glover, 2003, p. 31, p. 31)

Additionally, Bush and Glover (2003) propose three dimensions of leadership: (1) leadership is a process of influence to structure and organise the processes in the organisation, (2) leadership is related to organisational values and committing people to these values and (3) vision is an essential feature of effective leadership.

Grissom and Loeb (2011, p. 1119) describe effective school leaders as leaders who manage to combine and understand the instructional needs of the school, have the ability to allocate resources where they are needed, hire and manage qualitative personnel and keep the school running.

For the sake of the present review study, leadership will be approached from a broader perspective than the instructional perspective. This allows to get a general insight in leadership in education and therefore, the following definition will be used:

Leadership in education is a process of influencing teachers and other stakeholders and is not necessarily limited to a single person. The process of influence ideally leads to an effective learning climate which all stakeholders (such as pupils, teachers, parents, society) experience as an added value and keeps all the organisational processes in the school (among others, monitoring the instructional process, managing personnel and allocating resources) running smoothly.

\section{Research questions and aims}

Reviews providing an overview of effective school leadership theories and effective professional development are rather rare, as well as studies investigating principals' professional development. Therefore, in order to map the existing literature and eventually construct a theoretical framework that can serve other studies on school leadership and school leadership development in preschools, primary and secondary schools, the present review was conducted. The general aim of this literature review is to identify lacunae in the literature, to eventually focus on relevant research topics aiming to contribute to the knowledge of school principals' leadership and the development of their leadership. Reviewing the evolvement of theories allows to understand past practices, which serve to understand and shape our present practices in a qualitative way. Moreover, the study aims to provide guidance for future research in school leadership and the development of effective leadership in practice. The present review raises three research questions:

(1) How did theories on school leadership evolve over time? Particular attention will be paid to the past 20 years.

(2) What are the key characteristics of effective leadership in an educational setting?

(3) How can school principals effectively develop their leadership?

\section{Method}

In order to answer the research questions, a narrative review was conducted on theories of school principals' leadership and a systematic review on the effectiveness of school leadership and professional development of school principals. The guiding questions from Hallingers' conceptual framework for conducting research reviews (Hallinger, 2013) provided guidance for the review study and are provided in Table 1.

Relevant articles were identified based on the criteria for in- and exclusion as clarified in Table 1. Same articles were sometimes identified in different databases. Therefore, only the number of unique articles selected from the particular search of the database are shown in Table 2. This explains the decreasing trend of selected articles. An overview of the main key search terms, the associated hits and the number of selected articles (between brackets) per main search word are also provided in Table 2 . The search words used, were determined starting from established theories. All search terms served the search for articles for the three interrelated research questions. A limited number of search words that still covers all selected articles are presented in Table 2 . Therefore, it may seem that with regard to RQ 1, the researchers only sought for a limited number of search words. Though, all presented search words have served the search for articles to answer the three RQ's of the present study. 
Table 1

Guiding questions for systematic reviews (Hallinger, 2013) applied to the present study.

Constructs based on the guiding questions from Hallingers' conceptual framework (Hallinger, 2013)

Central topics, research questions and goals

Conceptual perspective

Sources and types of data

Nature of data evaluation and analysis
Application in the present study

\section{Central topics}

Recent developments in school leadership theories

Effective school leadership

School principals' professional development

Preschools, primary and secondary schools

The research questions (RQ's) in the present study

(1) How did theories on school leadership evolve over time? Particular attention will be paid to the past 20 years.

(2) What are the key characteristics of effective leadership in an educational setting?

(3) How can school principals effectively develop their leadership?

\section{Goal}

The review aims to draw together and synthesise the literature in order to contribute to a better understanding and to provide an overview of what is currently known about school leadership. This review also aims to identify lacunae in the research field of leadership in an educational setting in order to focus on relevant research topics in future research.

The present review synthesises the literature on leadership theories in an educational setting and further considers: the characteristics of effective school leadership and the professional development of school principals.

The present review syntheses the literature on leadership theories in an education settings and considers the following concepts: leadership theories with a wide conceptualisation of leadership not solely studying a particular aspect of leadership, characteristics of effective school leadership and professional development of school leadership.

In order to select appropriate studies several search engines and databases such as ERIC (Educational Resource Information Centre), Google Scholar and Limo were searched. Limo is a discovery service and searches among others the following databases: Psychlit, Econlit, Web of Science, Scopus and Taylor, Francis and LIBISnet, a scientific library network with access to collections of over 80 libraries. Subsequently, Educational Research Review, Review of Educational Research and School Leadership \& Management, were hand searched. Over 2000 abstracts and introduction sections originating from peer-reviewed journals were scanned, using the below mentioned criteria for in- and exclusion. The reference sections of all included studies were searched for more relevant studies as well. Eventually, 75 studies that met our criteria were selected to answer the three interrelated RQ's of the present review.

A systematic review is characterised by the use of techniques to minimise bias and by following criteria for searching for relevant studies (Cohen et al., 2011). Hence, the following selection criteria for inclusion were determined:

(1) predominantly focusing on: school leadership, characteristics of effective school principals and school principals professional development;

(2) recent articles: the searches were limited to articles published between 1996 and 2017; The answer of RQ 1 provides a historical overview of leadership in an educational setting. Therefore some publications published before 1996 and a few books were included in order to provide a fuller picture of the early theories.

(3) articles originating from peer-reviewed journals considering research in an educational setting.

The following criteria for exclusion were determined: (1) predominantly focusing on teacher leadership;

(2) originating from development studies or developing countries;

(3) Asian studies for the sake of major contextual and cultural differences;

(4) studies evaluating outcomes of particular local training programmes or strongly focusing on a particular local context (hazardous for generalisations);

(5) solely reporting about research methods, research models or the use of measurement scales;

(6) studies considering higher education and university education;

(7) absence of a clear definition of leadership or the leadership theory.

Table 1 (Continued)

Constructs based on the guiding questions from Hallingers' conceptual framework (Hallinger, 2013)

Application in the present study

Major results

(1) An insight in the evolvement of school leadership.

(2) An overview of the characteristics of effective leadership and professional leadership development in an educational setting.

(3) An overview of the lacunae in the research field of effective school leadership and school leadership development.

The research questions serve research on the further development of school leadership theories. The overview of theories support studies on the contextualisation and validation of existing theories for specific regions which is meaningful, though currently gets limited attention. The research questions considering the characteristics of effective school leaders and leadership development offer for instance a starting point for research on the development of effective school principals and studies on the transfer of effective professional development for school principals. 
Table 2

Overview of hits and selected articles per main search words per database.

\begin{tabular}{|c|c|c|c|c|c|c|c|c|c|}
\hline \multirow[t]{2}{*}{ RQ 1 Leadership theory } & \multicolumn{3}{|l|}{ Limo } & \multicolumn{3}{|c|}{ Google Scholar } & \multicolumn{2}{|l|}{ ERIC } & \multirow{2}{*}{ Selected } \\
\hline & Hits & Scanned & Se-lected & Hits & Scanned & Se-lected & Hits & Scanned & \\
\hline Effective school leadership & 245368 & 213 & 1 & 1270000 & 209 & 3 & 1868 & 223 & - \\
\hline Instructional school leadership & 52114 & 238 & 7 & 261000 & 269 & - & 3562 & 229 & - \\
\hline Leadership for Learning & 353974 & 210 & 9 & 5600 & 201 & - & 5008 & 218 & - \\
\hline Distributed Leadership & 178188 & 212 & 8 & 1020000 & 243 & - & 982 & 200 & - \\
\hline Snowballing & & & 1 & & & & & & \\
\hline RQ 2 Effective school leadership & Hits & Scanned & Se-lected & Hits & Scanned & Se-lected & Hits & Scanned & Selected \\
\hline Effective school leadership & 245368 & 213 & 4 & 1270000 & 209 & - & 1868 & 223 & - \\
\hline Instructional school leadership & 52114 & 238 & 4 & 261000 & 269 & - & 3562 & 229 & - \\
\hline Effective leadership education & 318749 & 200 & 5 & 1370000 & 200 & - & 25583 & 216 & - \\
\hline Effective school principals & 52157 & 212 & 1 & 144000 & 231 & & 898 & 200 & - \\
\hline Principal + student achievement & 28396 & 207 & 2 & 18100 & 223 & - & 1186 & 213 & - \\
\hline Leadership + student achievement & 77643 & 204 & 1 & 654000 & 245 & - & 1948 & 201 & - \\
\hline Transformational leadership + learning & 24849 & 200 & 3 & 75800 & 224 & - & 330 & 210 & 1 \\
\hline Personality traits of effective school leaders & 11530 & 202 & 1 & 17600 & 200 & - & 2374 & 200 & - \\
\hline Snowballing & & & 1 & & & & & & \\
\hline \multicolumn{10}{|l|}{ Hand searches: } \\
\hline Review of Educational Research & & & 1 & & & & & & \\
\hline Journal of School Leadership \& Management & & & 1 & & & & & & \\
\hline RQ 3 School leadership development & Hits & Scanned & Se-lected & Hits & Scanned & Se-lected & Hits & Scanned & Selected \\
\hline School leaders professional development & 165513 & 202 & 5 & 1400000 & 202 & 2 & 15634 & 200 & - \\
\hline School leaders learning & 194373 & 210 & 3 & 1530000 & 215 & - & 2226 & 201 & - \\
\hline School leadership development & 346553 & 200 & 5 & 1460000 & 212 & - & 4304 & 209 & 1 \\
\hline Leadership studies education & 394221 & 203 & - & 1400000 & 211 & 1 & 6279 & 206 & - \\
\hline Snowballing & & & 1 & & & & & & \\
\hline
\end{tabular}

At least the first 200 abstracts per search word per database were carefully read. Thereafter, relevance often decreased and further reading of abstracts was based on the estimation of the authors. In case articles originate from searches in the reference sections of articles, they are indicated at the bottom of the row of the respective research question and are described as 'snowballing'. The selected articles are indicated by an asterisk in the reference list.

The present study aims to draw together the literature on school leadership theories and school leadership development. Hence, the analyses were conducted inductively in order to let theory emerge from the selected articles (Cohen, Manion, \& Morrison, 2011). RQ 1 was answered based on a narrative analysis. It was chosen to start with a narrative analysis because a narrative review is helpful in the initial phase of a research (Popay, Roberts, Sowden, Petticrew, Aria, Rodgers et al., 2006). Indeed, a narrative review facilitates the exploration of the field, guides the next steps in the research and the choice of appropriate methods (Popay et al., 2006). The selected articles to answer the first research question were carefully read and summarized. The articles used to answer RQ 2 (What are the key characteristics of effective leadership in an educational setting?) and RQ 3 (How can school principals and supervisors effectively develop their leadership?) were analysed using NVivo 11. The full text of the articles were analysed. However, especially fragments in the results, discussion and conclusion sections were the most relevant for coding. First, the selected articles were accurately read to get a general overview of the articles. Based on this exploratory reading, a preliminary coding tree was constructed. Second, to further explore the selected articles, the articles were inductively coded to identify constructs and characteristics. During the development of the coding tree and the determination of the constructs, the determined constructs were clarified. Some construct clarifications are determined by the authors, whereas some clarifications build on existing definitions. Clarifications are helpful to structure the coding process and minimise bias. The development of the coding tree and the clarifications of the constructs were refined and adapted during the coding process. The clarification of the constructs can be consulted in the appendix. Third, the articles were coded. The codes considering RQ 2 \& RQ 3 were coded on the level of the school leader, because school leaders are the main focus of the present article. The construct clarifications guided whether or not to encode a particular fragment. Throughout the study, 322 fragments were coded to tackle RQ 2 and 117 fragments to tackle RQ 3. Fourth, the results from the open coding process were carefully investigated and eventually similar codes were merged. The frequencies of the codes were counted to determine the most frequently emerging codes. Besides, the coded fragments were summarized. The latter guided the eventual description of the findings. In the findings the characteristics of effective leadership and the prescriptive elements for school leaders' professional development are presented. A detailed description of the coding constructs after the merge can be found in table 5 in appendix A and table 6 in appendix B.

\section{Findings}

In this part, the evolvement of school leadership literature will be presented. Second, we focus on the key characteristics of effective school leadership and third, we discuss the development of principals' leadership. 


\subsection{Developments in leadership theories in educational settings}

The current paragraph answers the first research question: how did the theories of school leadership evolve over time. In the first subparagraph, the early theories are discussed whereas the recent theories are discussed in the second subparagraph.

\subsubsection{Early theories on leadership in education}

In this paragraph instructional, situational, transformational and distributed leadership are discussed. Instructional leadership, which focusses on the impact of teaching and learning, is since long considered as an important component of effective schools (Grobler, 2013; Hallinger, 2005; Robinson, Lloyd, \& Rowe, 2008). The concept of instructional leadership originates from the effective school studies in the 70s and 80s (Hallinger, 2005). Instructional leadership emphasizes the improvement of teaching and learning and focuses on the behaviour of teachers as they engage in activities directly influencing student achievement (Hallinger, 2003). Several conceptualisations of instructional leadership exist, but the most common conceptualisation is the one of Hallinger (2003) who defines instructional leadership using three dimensions: defining the school mission, managing the instructional programme and developing the school learning climate. Hallinger (2003) delineated these dimensions into ten instructional leadership functions. Defining the school mission is delineated in framing the school goals and communicating these goals (Hallinger, 2003). The functions coordinating the curriculum, supervising and evaluating instruction and monitoring the student process comprise managing the instructional programme (Hallinger, 2003). The last dimension, developing the school learning climate, is defined in the following functions: protecting the instructional time, providing incentives for teachers, providing incentives for learning, promoting professional development and maintaining high visibility (Hallinger, 2003).

Instructional leadership is defined as centred around the school principal (Aas \& Brandmo, 2016; Nedelcu, 2013). It can be characterised as a top-down approach to school leadership because it mainly focuses on the principal and their tasks in coordinating and controlling instruction (Aas \& Brandmo, 2016). Nedelcu (2013) states that Hallinger sees instructional leaders as hands-on principals, strongly focusing on the curriculum and unafraid of working with teachers on the improvement of teaching and learning. Instructional leadership is criticised by some scholars as being paternalistic and dependent on obedient followers (Marks \& Printy, 2003).

Although instructional leadership caught a lot of attention, other theories arose and instructional leadership faded more to the background. Leithwood (1992) explains this fade as a cause of the original narrow focus on the practices in the classroom. Nevertheless, instructional leadership nowadays regains more attention. Instructional leadership remains crucial because it focusses on the core process of schools: the quality of teaching and learning. Contemporary instructional leadership focuses on influencing processes of teaching and learning, but also recognises that leadership has to consider the organisational conditions for teaching and learning (Piot, 2015).

The effective school studies in the 70s and 80s focused on urban elementary schools in challenging circumstances. Some scholars questioned if and how the results of these urban school studies could be generalised to a wider population of schools (Bossert, Dwyer, Rowan, \& Lee, 1982). This critique implicitly recognises that the school context represents an important factor in school leadership and school effectiveness (Bossert et al., 1982) and is consistent with the situational leadership theories which emerged in the 70s. Situational leadership states that employees should be treated according to the particular dynamics of the situation and that leaders should be aware of opportunities to improve employees skills and confidence (Thompson \& Glasø, 2015). Situational leadership theories rather focus on behaviour and attitude of the employee and on characteristics of the organisation e.g. the staff characteristics, task structure, hierarchy and power relations. Since the 70 s, the belief that the outcomes of leadership are influenced by the context are generally accepted. All the same, Bass and Riggio (2006) acknowledge that situational factors can influence the effectiveness of leaders. After a period of declined attention to situational leadership, the relationship between the school context and leadership has recently raised again (Hallinger, 2011).

The concept of transformational leadership arose in the 80's and emphasizes that leaders should motivate followers to work towards transcended goals and towards achievement and self-actualisation (Sun \& Leithwood, 2012). It aims to foster capacity building and higher levels of personal commitment to organisational goals, leading to increased effort and productivity (Bass \& Avolio, 1994). Leithwood (1992) adapted the general model of transformational leadership into a model of transformational leadership in an educational setting. This model consisted out of seven components: individualised support, shared goals, vision, intellectual stimulation, culture building, rewards, high expectations and modelling. Later Leithwood and Jantzi (1999) developed a more comprehensive transformational school leadership model based on six leadership dimensions and four management dimensions. These leadership dimensions include: building school vision and goals, providing intellectual stimulation, offering individualised support, symbolising professional practices and values, demonstrating high performance expectations and developing structures to foster participation in school decisions (Leithwood \& Jantzi, 1999). The management dimensions include: staffing, instructional support, monitoring school activities and community focus (Leithwood \& Jantzi, 1999). Additionally, Marks and Printy (2003) emphasize that transformational school principals motivate teachers and students by raising their consciousness about the organisational goals.

Transformational leadership contrasts with instructional leadership as it is described as a shared leadership model and aims to create change through bottom-up actions (Aas \& Brandmo, 2016). Hence, transformational leadership is related to leadership models which focus on collaboration. Indeed, Hallinger (2003) states that instructional leadership focusses on how to manage and control staff in the direction of the defined goals and thereby characterises instructional leadership as a top-down approach (Aas \& 
Brandmo, 2016). Transformational leadership is more important for school improvement and student achievement (Leithwood \& Jantzi, 1999; Leithwood \& Sleegers, 2006; Sun \& Leithwood, 2012). Obviously, some transformational leadership practices make much larger contributions to student achievement than others. Sun and Leithwood (2012) state that especially building collaborative structures and providing individualised consideration make large contributions to student achievement. In addition, Sun and Leithwood (2012) argue that in educational settings, the inclusion of instructional management dimensions makes transformational school leadership more relevant for schools. Transformational leadership attenuates the importance of the context and situational effects. By claiming that transformational leadership is valid across situations and cultures, Bass downplayed the importance of situational effects (Yu, Leithwood, \& Jantzi, 2002). Nevertheless, evidence concerning this claim in school contexts is not conclusive.

In the late 80s a new trend in leadership models developed. Leadership models oriented towards collaboration and organisational learning, such as distributed leadership, shared leadership, team leadership and democratic leadership emerged (Hallinger, 2003). The emergence of these models indicated dissatisfaction with instructional leadership that mainly focuses on the power and authority of the principal and suggests that teachers are just obedient followers (Nedelcu, 2013). Distributed leadership recognises that leadership can be distributed along all school members. So far, no agreed definition of distributed leadership exists (Harris, 2013). Spillane (2006) states that distributed leadership is stretched over a number of individuals and tasks are accomplished through the interaction of multiple leaders. Harris and De Flaminis (2016) posit that distributed leadership considers leadership by teams and groups, that is shared within, between and across organisations. Distributed leadership emphasize interactions rather than actions and states that leadership is not restricted to those with a formal leadership position at the top of the organisation (Harris \& De Flaminis, 2016). So multiple individuals share the leadership responsibilities to guide and complete leadership tasks that vary in size, complexity and scope (Harris \& De Flaminis, 2016). This implies that different individuals can be in charge at different times depending on the specific challenge and the specific context (Gronn, 2002). Robinson (2008) has suggested that the nature of distributed leadership encompasses two main concepts: (1) distributed leadership as task distribution and (2) distributed leadership as distributed influence processes. Distributed leadership highlights the benefits of collaboration, shared purpose and shared ownership but much of its effect depends on how leadership is distributed and the intentions behind it (Harris, 2013). Mascall, Leithwood, Strauss, and Sacks (2008) stress the responsiveness of distributed leadership to its context.

Heck and Hallinger (2010) indicate that the impact of distributed leadership in schools is achieved through improved communication of mission and goals, better alignment of resources and structures to support students, more active engaged professional learning among staff, and the ability to maintain a focus on innovations in teaching and learning. This has clearly similarities with instructional leadership which emphasizes defining the school mission and the development of a learning climate. Leithwood, Harris, and Hopkins (2008) indicate the importance of distributed leadership for pupils and schools achievement. They state that the influence of distributed leadership on schools and pupils is enhanced when school leadership is widely distributed. Nedelcu (2013) and Penlington, Kington, and Day (2008) point the importance of teacher participation in distributed leadership, wherein teachers are seen as experts to be involved in the school improvement process.

In the previous paragraphs, an overview of main leadership theories was provided. Before the more recent theories are discussed, a summary of the common constructs in the discussed leadership theories is displayed in Table 3.

\subsubsection{Recent leadership theories}

Leadership in education was often investigated from the narrow perspective of a single theory itself or solely from the point of the principal. The fact that school principals are hold accountable for the learning of their pupils, the multiple tasks they need to fulfil and the increasing pressure on school principals, implicates that leadership today is distributed or seen as a collective activity (Leithwood et al., 2008). Furthermore, scholars paid a lot of attention to instructional leadership. Piot (2015) states that the theory on instructional leadership and how to bring this into practice is vague and therefore advices to integrate other relevant theories. Marks and Printy (2003) state that when instructional leadership, transformational leadership and shared leadership are integrated, the influence on school performance and student achievement is meaningful. Robinson et al. (2008) note that successful school lead-

Table 3

Overview of common constructs in the discussed leadership theories.

\begin{tabular}{|c|c|c|c|c|}
\hline & $\begin{array}{l}\text { Instructional } \\
\text { Leadership }\end{array}$ & $\begin{array}{l}\text { Situational } \\
\text { Leadership }\end{array}$ & $\begin{array}{l}\text { Transformational School } \\
\text { Leadership }\end{array}$ & $\begin{array}{l}\text { Distributed } \\
\text { Leadership }\end{array}$ \\
\hline Mission, vision, goals & $\mathrm{X}$ & & $\mathrm{X}$ & $\mathrm{X}$ \\
\hline Communicating mission, vision Focus on instructional & $\mathrm{X}$ & & $\mathrm{X}$ & $\mathrm{X}$ \\
\hline programme & $\mathrm{X}$ & & & \\
\hline Professional Development & $\mathrm{X}$ & & & \\
\hline Top-down & $\mathrm{X}$ & & & \\
\hline Bottom-up & & & $\mathrm{X}$ & $\mathrm{X}$ \\
\hline Context & & $\mathrm{X}$ & & $\mathrm{X}$ \\
\hline $\begin{array}{l}\text { Characteristics of the organisation (staff, hierarchy, } \\
\text { power) }\end{array}$ & & $\mathrm{X}$ & & \\
\hline $\begin{array}{l}\text { Motivating staff towards achievement and self- } \\
\text { actualisation }\end{array}$ & & & $\mathrm{X}$ & \\
\hline Collaboration & & & & $\mathrm{X}$ \\
\hline Leadership by multiple leaders, teams and groups & & & & $\mathrm{X}$ \\
\hline
\end{tabular}


ership coexists with a focus on instructional leadership, because instruction as a specific process is lacking in more general leadership theories such as transformational leadership (Robinson et al., 2008). Thus, it is fruitful to extend instructional leadership with other theories in order to get a deeper insight in the effect of school leadership on student achievement. Finally, the school context in school leadership research is currently considered again (Hallinger, 2011).

Nowadays leadership in education is mainly investigated on the basis of previously discussed theories: instructional, distributed and/or transformational leadership. Though, recently 'Leadership for Learning' (LfL) emerged in school leadership research. Given the fact that instructional, distributed and transformational leadership are discussed more extensively in previous paragraphs, the following paragraphs focus on LfL. Leadership for Learning integrates different aspects of previous theories, for instance instructional leadership, situational leadership, transformational leadership and distributed leadership. In addition, LfL aligns with scholar's above-mentioned suggestions to use multiple theories in school leadership research. Hence, LfL is elucidated in the following paragraphs.

Leadership for Learning (LfL) arose as a reaction to the perceived limitations of instructional leadership (Bush, 2013). Initially, LfL was a phenomenon of interest in Northern America, but in the past 15 years LfL became a global phenomenon receiving substantial attention from leading scholars (Hallinger \& Huber, 2012; Marsh, 2015). LfL mainly appears in research in education. Although 'Leadership for Learning' has gained popularity in recent research on school leadership, there is no solid definition of LfL. LfL is often understood as the process in which the whole school community actively participates in the improvement of learning (Marsh, 2012). Hallinger (2011) on the other hand, emphasizes that LfL refers to the actions school leaders enact to achieve school outcomes, especially with regard to student learning. Murphy, Elliott, Goldring, and Porter (2007) state that LfL is especially visible in high performing schools. They formulate the following touchstones for the conception of LfL: first, staying focused on learning, teaching, curricula, and instruction and second to make all the other dimensions of schooling (e.g. administration, organisation, finance) work, aiming to improve student learning (Murphy et al., 2007).

They further capture leadership for learning under eight major dimensions: vision for learning, instructional programme, curricular programme, assessment programme, communities of learning, resource acquisition and use, organisational culture and advocacy (Murphy et al., 2007). Especially the dimensions vision for learning, instructional, curricular and assessment programme align with the earlier mentioned functions of instructional leadership and are further elucidated in Table 4.

Leadership for Learning as conceptualised by Murphy et al. (2007) integrates features of instructional leadership, transformational leadership, distributed leadership and situational leadership. Moreover, LfL describes several approaches of leadership to school achievement with a specific focus on learning for students and for teachers as well. Fig. 1 clarifies our interpretation of the relation between instructional, transformational, distributed and situational leadership on the one hand and LfL on the other hand. Fig. 1 was constructed based on the narrative review conducted to answer the first research question.

The conceptualisation of LfL is not restricted to Murphy et al. (2007). The conceptualisation of other authors is additionally discussed to get a nuanced picture of the existing literature on LfL. The literature is summarized based on the five most recurrent features emerging from our literature review.

(1) Leadership for Learning assumes a wide range of leadership sources, which contrasts with leadership mainly centred around the principal in instructional leadership (Aas \& Brandmo, 2016; Marsh, Waniganayake, \& De Nobile, 2013; Nedelcu, 2013; Townsend, Acker-Hocevar, Ballenger, \& Place, 2013). LfL is team-oriented and collaborative and refers to school-wide leadership by those in formal management roles f.i. principals, assistant principals or coordinators and by those in less formal management roles f.i. teachers, parents or students (Marsh et al., 2013). The collective nature of LfL aligns with distributed leadership. LfL is a process in which the whole school community actively engages in purposeful interactions that nurture relationships focused on improving learning (Marsh, 2012).

(2) LfL is designed to create learning at all levels within a school system: student learning, teacher learning, organisational learning and leadership learning (Hallinger \& Heck, 2010; Townsend et al., 2013). Learning is especially influenced when schools are intentional about the language they use for both learning and leadership (Marsh et al., 2013). Furthermore, Marsh et al. (2013) conceptualise LfL as a relational and learning focused activity.

(3) The third feature, capacity building, subsumes according to Fullan (2006) policy, strategy or actions to increase the collective efficacy. Collective efficacy aims to improve student achievement through knowledge development, enhanced resources and a greater motivation on the part of the people working individually and together. Hence, capacity building is linked with student achievement. The capacity building perspective is supported by findings from studies of transformational school leadership (Leithwood \& Jantzi, 1999; Marks \& Printy, 2003).

(4) LfL is result-oriented, has an explicit focus on student achievement (Hallinger, 2011) and aims to impact school performance (Hallinger \& Heck, 2010) through creating and sustaining a schoolwide focus on learning. Murphy et al. (2007) define a wider approach of achievement and name the importance of staying focused on the core technology of schooling, learning, teaching, curriculum development and assessment. Besides, they emphasize that one should work on all other dimensions of schooling f.i. administration and finance, in view of improved student learning. Townsend et al. (2013) further argue that focusing on learning for all stakeholders is the best way to improve outcomes, because improving relies on interacting comprehensively with one's environment. More specific, LfL stresses the importance of individual skill development f.i. instructional strategies and self-awareness. Besides, LfL stresses the group process and relational skills as openness and conflict approaching (Townsend et al., 2013). 
Table 4

Elucidated dimensions of Leadership for Learning adapted from Murphy et al. (2007), p. 182.

Dimensions of Leadership for Learning

1Vision for Learning

ADeveloping vision: crafted and supported by the school community

BArticulating vision: translating the vision into specific and measurable results

CImplementing vision

DStewarding vision

2Instructional Programme

AKnowledge and involvement

BHiring and allocating staff: values and competencies have to align with the mission and culture

CSupporting staff: in teaching and learning and by providing sufficient materials

DInstructional time: making sure that a maximum of time is devoted to instruction

EProviding recognition and rewards for qualitative teaching

3Curricular Programme

AKnowledge and involvement

BEstablishing high expectations and standards

CMaximizing the learning opportunities for all pupils

DCurriculum alignment: ensuring the coordination of objectives, instruction, materials and assessments

4Assessment Programme

AKnowledge and involvement

BMonitoring assessment procedures

CMonitoring instruction and curriculum

DCommunication and use of data with regard to improvement

5Communities of Learning

APromoting staffs professional development

BNurturing the growth of communities of professional practice

6Resource Acquisition and Use linked to the schools' mission and goals

AAcquiring resources

BAllocating resources

CUsing resources

7Organisational Culture

ACreating a high performance organisation with focus to the core processes

BEstablishing a safe learning environment

CEnsuring personalised environments: creating multiple options for meaningful student engagement

DEnsuring continuous improvement

8Social Advocacy

AStimulating and maintaining stakeholders engagement

BRecognising and utilising cultural, ethnical and economic diversity

CActively employing the environmental context

DLiving up to professional codes of ethics

Fig. 1. Relation between Instructional, Transformational, Distributed and Situational Leadership and Leadership for Learning (The figure was constructed based on Aas \& Brandmo, 2016; Bass \& Riggio, 2006; Gronn, 2002; Hallinger, 2003; Hallinger, 2011; Harris \& De Flaminis, 2016; Murphy et al., 2007; Robinson, 2008; Spillane, 2006; Sun \& Leithwood, 2012; Thompson \& Glasø, 2015). 
(5) Lastly, unlike earlier models as instructional leadership or transformational leadership, LfL emphasizes the relationship between school leadership and the organisational and environmental context (Hallinger, 2011).

\subsection{Characteristics of effective school leadership}

While scholars have long recognised that the situation is a critical consideration in studying leadership and management (Bossert et al., 1982; ), from a distributed perspective, aspects of the situation do not simply 'affect' what school leaders do or moderate the impact of what they do. Rather, the situation is one of the three core constituting elements of practice. At the same time, aspects of the situation are a product of practice ). Viewed this way, the practice of leading and managing is an emergent phenomenon (Gronn, 2002).

Scholars from diverse research fields have concluded that leadership is central in organisational performance (Murphy et al., 2007). In addition, the literature on school development emphasizes the impact of leadership on the success and the effectiveness of schools (Murphy et al., 2007; Salo, Nyland, \& Stjernstrøm, 2015; Simkins, 2005). School effectiveness refers to the extent of achieving the outcomes the school intends to achieve and mainly considers the schools' impact on pupils' educational achievement (Hobbs, 2016). Principals have a considerable potential to enhance student achievement through their influence on teachers and organisational processes (Grissom, Loeb, \& Master, 2013; Hallinger et al., 1996). The effect of principals on student achievement is often indirect and mediated through e.g. the principal-teacher relation and quality of instruction (May, Huff, \& Goldring, 2012). Nevertheless, research has shown that the impact of leadership on student achievement ranges from rather weak to strong (Kondacki \& Sivri, 2012; May et al., 2012; Robinson et al., 2008; Witziers, Bosker, \& Kruger, 2003). Yet, recognising that principals have an influence differs from 'how' principals can influence student achievement (Grissom \& Loeb, 2011). As principals can have an influence on the effectiveness of schools including student achievement, the second research question: 'What are the key characteristics of effective leadership in an educational setting?' is tackled in the following paragraphs.

Reviewing the literature, five main categories of effective school leadership raised and are presented according to their ranking.

(1) Effective schools have school leaders who focus on curricula and instruction. This appears to be the most mentioned characteristic of effective school leadership in the consulted literature. Focusing on curricula and instruction includes f.i. spending time on the development of the educational programmes, overseeing the educational programs developed by teachers, and monitoring instruction and student achievement (Dös \& Savas, 2015; Grissom et al., 2013; Kondacki \& Sivri, 2012; Malone \& Caddell, 2000; Parylo \& Zepeda, 2014; Pashiardis, 1998; Supovitz, Sirinides, \& May 2010; van der Werf, 1997). An active support of instruction, positively influences the development of a positive school climate and culture (Supovitz et al., 2010).

(2) Second, effective communication and maintaining good internal and external relations came out. Communication is often linked to communicating the vision and achievement standards, which contributes to commitment to the organisation, and the development of school climate and culture (Dös \& Savas, 2015; Grissom \& Loeb, 2011; Kruger, 2009; Land, 2002; Leithwood \& Jantzi, 2005; May et al., 2012; Ross \& Gray, 2006; Sahenk, 2010). Effective communication and relationships is not just about a one-way communication but gives a voice to teachers (Schneider \& Burton, 2005). It creates opportunities to involve teachers in policy and decision-making (Schneider \& Burton, 2005). Involvement in the decision-making process itself, not solely as an outcome of qualitative communication, is also often cited as a feature of effective school leadership (Kondacki \& Sivri, 2012; May et al., 2012). Furthermore, maintaining good internal and external relations includes representing the school and its members and maintaining good relations with the differing stakeholders: staff, parents and other relevant external and internal stakeholders (Grissom \& Loeb, 2011; Kondacki \& Sivri, 2012; Land, 2002; Malone \& Caddell, 2000; Parylo \& Zepeda, 2014; Pashiardis, 1998; Sahenk, 2010).

(3) The ability of a school principal to shape the organisational climate and culture and some related constructs such as trust and collaboration, are the third most mentioned characteristics of effective school leadership. The organisational climate influences the behaviour of people in the organisation and distinguishes the organisation from other organisations (Hoy \& Miskel, 2013). Hoy and Clover (1986) defined climate as 'a relatively enduring quality of the school environment that is affected by the principals' leadership, is experienced by teachers, influences members' behaviour and is based on collective perceptions'. On the other hand, culture is considered as the whole of norms, values and rituals that hold the organisation together and give the organisation a distinctive identity (Heck \& Marcoulides, 1996; Schein, 1996). Several studies identify principals as a central shaper of the school culture (Dös \& Savas, 2015; Malone \& Caddell, 2000; Supovitz et al., 2010). In clarifying the (learning) culture of a school organisation, trust and collaboration are mentioned (Marsh, 2015; Supovitz et al., 2010). The organisational culture and climate are explained emphasising the mutual trust between teachers and in the relation between the principal and the teachers (May et al., 2012; Supovitz et al., 2010). More specifically, school principals who build trust with their staff, contribute to improved student achievement (May et al., 2012; Supovitz et al., 2010). Facilitating collaboration is an aspect of the schools' culture as well and has a positive effect on student achievement (May et al., 2012).

(4) The principals' involvement in defining and sustaining the schools' vision and mission, but also effectively implementing the schools' vision and mission, influences school improvement (Dös \& Savas, 2015; Kruger, 2009; Kurland, Peretz, \& Hertz-Lazarowitz, 2010; May et al., 2012; Sahenk, 2010). Effective school principals hold high expectations for their staff and students (Pashiardis, 1998; Sahenk, 2010; Supovitz et al., 2010) and are also fully aware of the needs of their faculty and help them reaching their goals (Grissom et al., 2013; Sahenk, 2010). In order to achieve the mission and vision, school leaders need to motivate the organisation members to ensure they contribute to the achievement of the mission and vision as well. 
(5) Effective school principals give frequent feedback and recognise and award accomplishments (Dös \& Savas, 2015; Ross \& Gray, 2006; Sahenk, 2010; Supovitz et al., 2010). They reward success, significant achievements and important contributions to the school organisation (Dös \& Savas, 2015). School principals are likely to be particularly influential when they attribute school outcomes to particular teachers and the actions they undertook (Ross \& Gray, 2006). Feedback and recognition lead to the improvement of teachers' self-efficacy and their commitment to the organisation (Ross \& Gray, 2006).

(6) Lastly, the ability to invest in personnel by hiring and retaining qualified teachers is important (Hitt \& Tucker, 2016; May et al., 2012; Odhiambo \& Hii, 2006). Retaining qualified teachers includes that principals encourage teachers to dedicate time to continuous professional development and enable them to learn through creating a supportive organisation for learning (Hitt \& Tucker, 2016; May et al., 2012; Sahenk, 2010). By all means, the gained knowledge and skills should be used to tackle the needs and demands of the environment in order to contribute to the effectiveness of the school.

In addition, the school context is explicitly alleged. The school context itself is not a characteristic of effective leadership, but is mentioned by several scholars as an influencing factor on the action principals take to successfully improve teaching and learning and the overall school performance (Grissom et al., 2013; Kruger, 2009; Malone \& Caddell, 2000; Simkins, 2005; Supovitz et al., 2010) and therefore has to be taken into account as well while investigating effective school leadership.

Little research has focused on school leaders' personality traits or personal competences to engage in effective leadership (Leithwood et al., 2008; Robinson, 2010). Nevertheless, some scholars name the importance of personality traits or competences that indicate why some principals are more effective than others (Grissom et al., 2013). Besides, Kruger (2009) names the importance of competences and more in particular higher-order thinking. Kruger (2009) describes higher-order thinking as 'the ability of a school leader to act between the differing factors that influence student achievement: vision, school's community, the context and the organisational and cultural characteristics of the school.' Leithwood et al. (2008) indicate the importance of commitment to data-based decision making, an open-minded attitude and the readiness to learn from others, as important aspects of effective school leaders. Yet, there is no list of conclusive personality traits for school leaders. One of the reasons for the latter can be the influencing role of context on the necessary personality traits in school leadership.

\subsection{School principals' leadership development}

The vast majority of school principals in elementary schools previously used to be a teacher. Even so some of them did not follow a leadership training before entering the role of principal and often acquire skills while they are performing the job. Hence, school leaders in-service professional development is of interest. In this part, the third research question: 'How can school principals effectively develop their leadership?' is answered.

The literature provides several interchangeable concepts of in-service professional development. The most used concepts are continuous professional development (CPD) and workplace learning. Both concepts explain professional development (PD) which can be structured and organised in a number of different ways including many different forms of professional development in face-to-face and online contexts (Peterson, 2002; Stevenson, Hedberg, O'Sullivan, \& Howe, 2016) aiming to keep knowledge, skills and/or attitudes up to date. Professional development activities range from formal training sessions to informal interactions at the workplace (Goldring, Preston, \& Huff, 2012). Tynjälä (2013) identified three modes of workplace learning: incidental and informal learning, intentional but non-formal learning and formal training. Incidental and informal learning are side effects of work. Non-formal learning, is related to work and occurs f.i. as coaching or reflecting about a work experience. Formal trainings include lectures, trainings, workshops and courses. Distinguishing between the concepts of incidental and informal, intentional but non-formal and formal learning does not mean these interrelated concepts have to be approached as a strict trichotomy. Informal learning opportunities around formal events are often responsible for unexpected and influential transformations (Cramp, 2016). Cramp (2016) investigated school leadership development through an international study visit and found among others that school leaders indicate informal discussing as fruitful. Informal conversations allow to test out views and opinions they would not have shared with larger and more formal groups because they appoint to feel more eased in informal conversations (Cramp, 2016). Another example of incidental and informal learning in Cramp's study was that participants started to make school action plans during travelling and social time (Cramp, 2016). Yet, informal learning opportunities are often undervalued and under researched in the context of school principals' professional development (Cramp, 2016; Hulsbos, Evers, \& Kessels, 2016).

Besides Tynjälä's trichotomy of workplace learning, we mention Hubers approach to school leaders' professional development. Huber (2011) distinguishes regarding to school leaders' PD, between cognitive theoretical ways of learning, cooperative and communicative process-oriented procedures, and reflexive methods. Cognitive theoretical learning includes among others lectures and self-study, cooperative and communicative process-oriented procedures include f.i. group and project work and reflexive methods contain methods such as feedback and supervision.

In the present study, we opt to use the term professional development as a collective noun to indicate all learning activities that aim to contribute to one's professional development.

Research on how effective leadership development takes place is still in its infancy. Studies providing an overview of the undertaken professional development activities of principals' and school principals' needs or preferences for professional development activities are hard to find. Most studies focus on formal trainings, often aiming to train aspiring or novice principals, or on a particular technique such as mentoring. Research results regarding the effectiveness of the various types of school principals' professional development learning are lacking as well (Helsing, Howell, Kegand \& Lahey, 2008; Nicolaidou \& Petridou, 2011). Especially 
research about informal workplace learning of school principals is rare (Hulsbos et al., 2016; Zhang \& Brundrett, 2010). Consequently, a clear and useful framework about qualitative professional development for school principals is missing (Goldring et al., 2012; Wright \& da Costa, 2016). However, the literature offers common prescriptive elements to consider while developing professional development activities for school principals. These common elements will be elucidated in the following paragraphs and are presented in a logical order of development of PD. The ranking of the categories are displayed in table 6 (see appendix B). It was chosen to discuss the five most cited categories. Some of the categories are the result of a merging of codes because of their mutual connection. In case codes are merged, it is mentioned in the relevant paragraph.

First, professional development curricula should be carefully designed and sequenced with attention to prior learning and must consider the individual development needs of the principal (Goldring et al., 2012; Huber, 2013; Peterson, 2002; Simkins, 2012; Wright \& da Costa, 2016). PD activities should also consider the working experience of principals and take into account the needs of aspiring, novice and experienced principals (Peterson, 2002).

Second, professional development for school principals should be contextual and experiential (Goldring et al., 2012; Gunter \& Ribbins, 2002; Reeves, Forde, Casteel, \& Lynas, 1998; Wright \& da Costa, 2016). This paragraph is a result of the merging of the codes 'considering the context and own practice' 'experiential learning', 'reflective learning' and 'action research' because these codes all refer to learning linked to own practices and experiences. The first part of the current paragraph pays attention to the context whereas the second part focuses on experiential learning. Professional development influences and is influenced by the organisational context in which it takes place and must be aligned to the particular context (Goldring et al., 2012; Wright \& da Costa, 2016). Gunter and Ribbins (2002) and Simkins (2012) emphasize the importance of authentic experiences in school environments. Zhang and Brundrett (2010) state that external training programmes are not able to prepare and develop effective leaders without support from the school context itself. Successful professional development programmes are embedded in authentic school environments to allow participants to apply what they have learned (Goldring et al., 2012; Simkins, 2012) and strengthen learning on the individual and organisational level (Aas, 2016). Apart from the context, experiential learning is a focus in this paragraph. Zhang and Brundrett (2010) especially value the techniques of mentoring, coaching and apprenticeship. Also Aas (2016), Aas and Vavik (2015) and Mac Beath (2011) emphasize the importance of coaching and reflective learning. Scott (2010) appoints mentoring as a fruitful way to develop school principals and especially values mentoring in combination with peer-coaching. According to Zhang and Brundrett (2010) school principals prefer mentoring and experiential learning rather than formal courses. Hulsbos et al. (2016) state that school principals mostly value workplace learning through working on improvement and innovation through reflection. Also Wright and da Costa (2016) point to reflection and state that reflection takes the form of problem solving and theory building and appreciates each unique situation through different perspectives. Additionally, Aas (2016) states that leadership development can occur through action research of school principals' own leadership practices (Aas, 2016). According to Aas (2016) development programmes should learn to tackle tensions, by learning to reflect on these tensions to eventually be able to effectively implement changes in daily practice (Aas, 2016).

Third, to obtain an effect of leadership development activities, the transfer of knowledge, skills and attitudes to practice is crucial (Aas, 2016; Huber, 2013). This paragraph was compiled based on the interrelated codes 'transfer of learning' and 'variety of techniques'. Huber (2011; 2013), Goldring et al. (2012), Forde \& Gronn, 2013 and Simkins (2012) propose the use of a range of learning activities in various formats. The range of learning activities include theoretical ways of learning f.i. via courses and lecturers, group work, projects and reflexive methods such as (peer) feedback and self-evaluation (Forde \& Gronn, 2013; Huber, 2011). Huber (2013) emphasizes the importance of the fit between the didactic approach of a programme and the participant needs in order to facilitate transfer from PD activities into principals' daily practice and consequently having a higher sustainability.

Fourth, networking and collegial consulting emerged. School principals learn when spending time networking with fellow principals by sharing ideas and through reactivating existing knowledge and practices (Goldring et al., 2012; Mac Beath, 2011). Networking and collegial consulting is meaningful in easing the feeling of loneliness which school principals often report (MacBeath, 2011) and contributes to greater confidence (Aas \& Vavik, 2015). Aas and Vavik (2015) state that school leaders develop greater confidence through personal and contextual feedback from other school leaders. Huber (2011) relates professional learning networks to reflection. He states that professional learning networks are central components in school leaders' professional development and posit that they provide chances for intensive reflection on one's own action and behaviour. Hulsbos et al. (2016) confirms that networks allow school leaders to reflect in a peaceful and stable way.

Lastly, Goldring et al. (2012), Peterson (2002) and Wright and da Costa (2016) emphasize that effective professional development is spread over time. MacBeath (2011) stresses the added value from ongoing support because it helps to extend and redefine their daily experiences (MacBeath, 2011).

\section{Discussion}

The literature provides a myriad of articles about leadership. However, leadership theories considering educational settings are less likely. In recent years, school leadership research also gained much more attention from researchers spread over Europe and other areas in the world. The following parts of this paragraph summarise and discuss the findings with regard to the research questions in this study. 


\subsection{Leadership in an educational setting}

Instructional leadership emerged about four decades ago as a leadership theory focusing on leadership in educational settings. Instructional leadership approaches leadership rather narrow: centred on the principal and mainly considering instruction and learning. All the same, leadership is meanwhile approached as going beyond the principal and seen as a process spread over several members of the whole school community. Furthermore, several scholars suggest to approach leadership in education from an integrative perspective, i.e. integrating various theories to get a thorough understanding of leadership and its effect on school performance. In addition to the integrative approach of leadership in an educational setting, it is important to consider instruction as a particular core process. Hence, Leadership for Learning was suggested in the context of leadership research in an educational setting. Leadership for Learning integrates features of instructional, transformational, distributed and situational leadership and can be linked to our analysis of the literature of effective school principals (see Fig. 1).

\subsection{Effective school leadership}

Reviewing the literature, we have determined characteristics of effective school leadership in preschools, primary schools and secondary schools. Effective school leaders focus on the schools' core process: curricula and instruction. An additional characteristic is effective communication and maintaining good relations. Effective communication contributes to two other characteristics: shaping climate and culture, and defining and sustaining the school mission. Lastly, human resource management in terms of recognising and awarding successes and investing in personnel by hiring and retaining qualified teachers were noted in the literature. It is striking that non-material characteristics such as effective communication and the ability to shape climate and culture are ubiquitous and on the other hand investigating the management of resources finance and infrastructure are hardly mentioned or investigated in school leadership. Little research has focused on school leaders' personality traits or competences they should possess to be effective. Hence, exploring school leaders' personality traits and competences, and investigating finance and infrastructure are suggested as subject for future research. A better understanding of school leadership is important because it is generally accepted that school leadership affects student achievement and the overall school performance.

Based on our review, we noticed strong similarities between the Leadership for Learning theory and the characteristics of effective school principals (see Fig. 2). Outstanding similarities are the agreements in the field of curriculum and instruction, vision, communication and organisational culture. Though, LfL should focus more explicitly on collaboration and recognition of staff's accomplishments in order to fully align with the characteristics of effective school principals. Moreover, the dimension 'resource acquisition and use' does not align with the characteristics of effective school principals emerging from the present review. Still, it is important to keep track of the finances in order to use the resources effectively for the purpose of qualitative school outcomes and education.

Fig. 2 clarifies the relation between Leadership for Learning and the characteristics of effective school principals.

\subsection{School principals' leadership development}

School leaders' professional development is still limited researched. Though, some similarities between school leaders' PD and LfL were noticed. LfL approaches leadership as a process in which the whole community participates (Marsh, 2012). School leaders' PD is like LfL seen as a process as it is suggested to spread school leaders' PD over time. Further, LfL recognises that learning goes be-

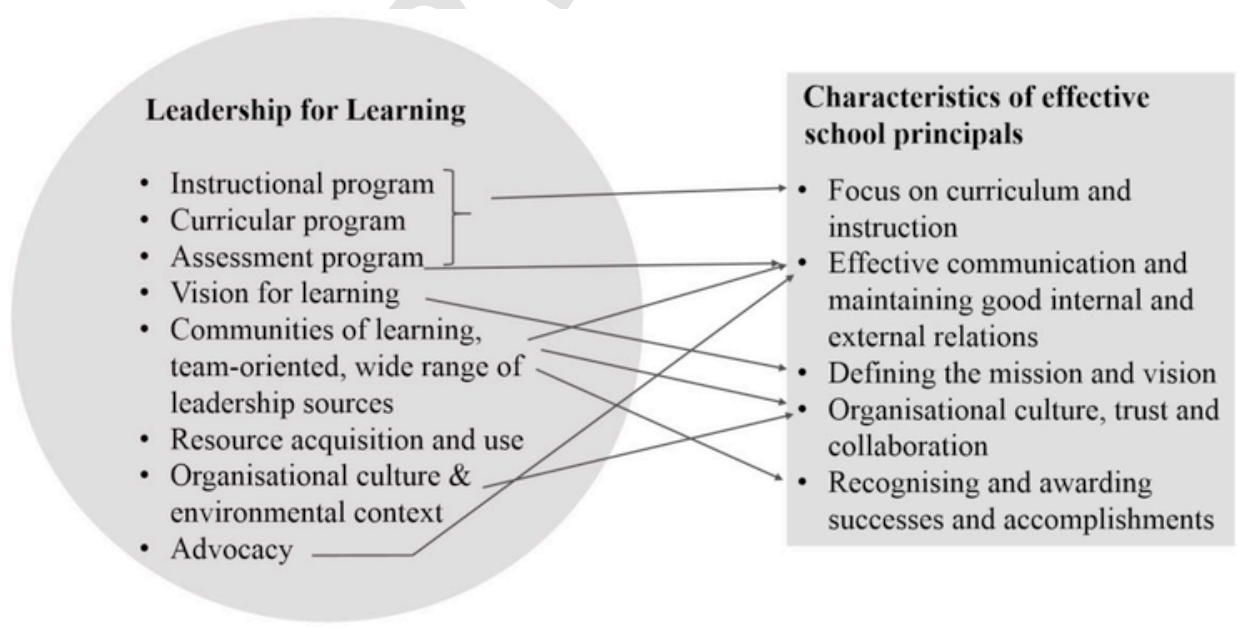

Fig. 2. Relation between Leadership for Learning and the characteristics of effective school principals The description of LfL is taken from Murphy et al. (2007). 
yond an individual and emphasize the importance of a learning community. This does not appear explicitly in the features of school leaders' PD, however the features of school leaders' PD recognise the importance of networking and collegial consulting. The latter aligns with both communities of learning and social advocacy of LfL, wherein the growth of communities, stakeholders engagement and the employment of the environmental context are named.

\section{Conclusion}

A lot of contemporary research builds on instructional leadership and transformational leadership. In the presented overview of leadership theories, it is noticeable that instructional leadership strongly focuses on the core process of education i.e. teaching and learning. Meanwhile, transformational leadership focuses on how to motivate staff in the direction of the school goals. The emergence of distributed leadership emphasizes that leadership is no longer only the responsibility of one formal leader. The importance of the context for leadership is often illuminated. Scholars therefore recommend to integrate several theories such as instructional leadership, transformational leadership and distributed leadership or propose a theory that integrates multiple theories such as LfL.

Effective leadership in education is often approached from the perspective of pupils' achievement. Though, principals have often an indirect effect on pupils' achievement through for example their influence on teachers. The characteristics of effective school leadership arising from the present study point among others to focus on curricula and instruction, communication and relations, the ability to shape the school climate and culture and hiring and retaining qualified teachers. Research considering school leaders' personality traits and school leaders' resource management in terms of finance and infrastructure are limited.

The concept of school leaders' professional development remains fairly vague. Existing research has predominantly focused on learning through formal trainings. Research on school leaders' informal learning appears only in a small number of studies. Moreover, studies about school leadership are mainly self-reported, and so mostly rely on the principals' perceptions. Scholars barely integrate or compare various PD techniques. Substantial research considering transfer of professional development activities and research measuring the effectiveness is lacking as well. Hence, we suggest that future research maps school leaders' current professional development and investigates school leaders' professional development needs, their preferences of PD techniques and motivation to participate in professional development. We also suggest that future research includes the perception of several stakeholders such as the board, staff members and parents. School context appears as a common theme throughout the different parts of the present study and is of influence on leaders' performance. Therefore, school context has to be integrated in research designs about the effectiveness of school principals and their PD.

It was attempted to carry out the study in a respectable way, though every study has its limitations. During the coding, school leadership was approached from a general point of view and hence the study addresses general characteristics. Given the fact that effectiveness criteria can slightly differ for the various theories of leadership, it is possible that more nuanced answers on RQ 2 (What are the key characteristics of effective leadership in an educational setting?) can be found, when the levels of the different theories are taken into account.

In summary, we can conclude that there is room to further investigate school leadership, much to discover about school leadership skills and the approach to effectively develop and conduct school leadership development.

\section{Appendix C. Supplementary data}

Supplementary data to this article can be found online at https://doi.org/10.1016/j.edurev.2019.02.003.

\section{Appendix A. Codes to tackle RQ 2}

Table 5

Code clarifications to tackle RQ 2 presented according to their ranking

\begin{tabular}{|c|c|c|}
\hline & Code & Clarification of the code \\
\hline 1. & Focus on curriculum & Managing the curriculum, supervising and evaluating instruction (adapted from Hallinger, 2003) \\
\hline 2. & Safe (learning) climate & Providing incentives for learning and promoting professional development (adapted from Hallinger, 2003) \\
\hline 3. & $\begin{array}{l}\text { Good relations and com- } \\
\text { munication }\end{array}$ & $\begin{array}{l}\text { Maintaining good relations and communication with the direct stakeholders e.i. teachers, the board, parents and pupils } \\
\text { (authors' definition) }\end{array}$ \\
\hline 4. & Vision and goals & $\begin{array}{l}\text { Clarifying and stimulating to put the vision and goals into practice } \\
\text { Communicating the vision and goals (adapted from Leithwood \& Jantzi, 1999) }\end{array}$ \\
\hline 5. & $\begin{array}{l}\text { Acknowledges teachers } \\
\text { and other motivation }\end{array}$ & $\begin{array}{l}\text { Encouraging teachers } \\
\text { Recognising achievements and contributions of teachers (adapted from Yukl, 2012) }\end{array}$ \\
\hline 6. & $\begin{array}{l}\text { High expectations for staff } \\
\text { and pupils }\end{array}$ & Empowering staff members and pupils to go for excellence (authors' definition) \\
\hline 7. & School context & $\begin{array}{l}\text { Surrounding neighbourhood of the school } \\
\text { The school size (e.i. number of pupils, teachers) (authors' definition) }\end{array}$ \\
\hline 8. & $\begin{array}{l}\text { Leadership, policy, budget- } \\
\text { ting }\end{array}$ & $\begin{array}{l}\text { Leadership: influence people to structure activities and relationships } \\
\text { Policy: the whole of setting goals and allocating resources to achieve the school results } \\
\text { Budgetting: finance and budget planning (authors' definition) }\end{array}$ \\
\hline
\end{tabular}




\begin{tabular}{|c|c|c|}
\hline 9. & $\begin{array}{l}\text { Supportive for teachers - } \\
\text { fair treatment }\end{array}$ & Providing support and equal treatment to teachers (adapted from Yukl, 2012) \\
\hline 10. & $\begin{array}{l}\text { Continuous professional } \\
\text { development }\end{array}$ & All techniques that contribute to the professional development of school leaders (authors' definition) \\
\hline 11. & Decision making & The proces of decision making and people involved in decision making (autors' definition) \\
\hline 12. & Evaluation & Developing and monitoring evaluation procedures (authors' defintion) \\
\hline 13. & Participation & Empowering teachers to be involved in policy (adapted from Yukl, 2012) \\
\hline 14. & $\begin{array}{l}\text { Monitoring the results of } \\
\text { the students }\end{array}$ & Monitoring the results of the students (authors' definition) \\
\hline 15. & Overarching care policy & $\begin{array}{l}\text { Actions taken by all school members to create an optimal development opportunities for pupils and staff. This relates to } \\
\text { learning and psychological, social and physical well-being of the pupils and staff. (authors' definition) }\end{array}$ \\
\hline 16. & Infrastructure & Buildings and materials that foster the process of schooling (authors' definition) \\
\hline 17. & Respresent others & Representing and defending the reputation of colleagues and the organisation (adapted from Yukl, 2012) \\
\hline 18. & Self-evaluation & Evaluations by the school leader of teachers (authors' definition) \\
\hline 19. & $\begin{array}{l}\text { Preparing to reach the } \\
\text { aims }\end{array}$ & Planning actions aiming to reach the school outcomes (authors' definition) \\
\hline 20. & Role model credibility & Leading by example and clarifying assignments and responsibilities (authors' definition) \\
\hline 21. & Classroom observation & Observing and evaluating teachers' and pupils' performances during teaching activities (authors' definition) \\
\hline 22. & Teacher performance & Hiring and retaining teachers, performance appraisals (authors' definition) \\
\hline
\end{tabular}

\section{Appendix B. Codes to tackle RQ 3}

Table 6

Code clarifications to tackle RQ 3 presented according to their ranking

\begin{tabular}{|c|c|c|}
\hline & Code & Clarification of the code \\
\hline 1. & Action research & $\begin{array}{l}\text { Educational processes where people work and learn together by tackling real issues and through reflection. (adapted from } \\
\text { Walia \& Marks-Maran, 2014) }\end{array}$ \\
\hline 2. & $\begin{array}{l}\text { Connection to prior } \\
\text { learning }\end{array}$ & Making connection to prior learning and experiences in order to facilitate integration (authors' defintion) \\
\hline 3. & $\begin{array}{l}\text { Considering school } \\
\text { context and own } \\
\text { practice }\end{array}$ & $\begin{array}{l}\text { Surrounding neighbourhood of the school } \\
\text { The school size (e.i. number of pupils, teachers) } \\
\text { Own experiences during daily practice (authors' definition) }\end{array}$ \\
\hline 4. & $\begin{array}{l}\text { Experiential learning } \\
\text { Coaching, mentoring } \\
\text { Supervision, Intervi- } \\
\text { sion }\end{array}$ & $\begin{array}{l}\text { Experiential learning can occur through the interrelated listed techniques. The listed techniques are often used interchangeably } \\
\text { or differently in different settings. Therefore this code includes cooperative human relationships in which actions, activities } \\
\text { and thoughts are discussed to elicit professional development. One definition is highlighted to guide the coding. } \\
\text { Coaching: 'an intensive and systematic facilitation of individuals or groups by using a wide variety of behavioural techniques } \\
\text { and methods to help them attain self-congruent goals or conscious self-change and self-development in order to improve their } \\
\text { professional performance' (adapted from Segers, Vloeberghs, Henderickx, \& Inceoglu, 2011) }\end{array}$ \\
\hline 5. & $\begin{array}{l}\text { International Study } \\
\text { Visits or Interna- } \\
\text { tional courses }\end{array}$ & $\begin{array}{l}\text { A visit to a school or institution abroad for knowledge exchange } \\
\text { A course in a country abroad (authors' definition) }\end{array}$ \\
\hline 6. & $\begin{array}{l}\text { Lectures, courses, } \\
\text { trainings }\end{array}$ & Formal, planned trainings focusing on knowledge transfer \\
\hline 7. & $\begin{array}{l}\text { Mutual learning, net- } \\
\text { working, collegial } \\
\text { consulting }\end{array}$ & Learning in relations with peers, colleagues, stakeholders, externals (authors' definition) \\
\hline 8. & Reflective learning & Reflective learning is a process of thinking and doing on order to acquire new skills (Schön, 1987) \\
\hline 9. & Spread over time & PD trajectories, several sessions spread over time (authors' definition) \\
\hline 10. & Theory & PD initiatives including theory (authors' definition) \\
\hline 11. & Transfer of learning & The extent in which the knowledge, skills and attitudes are effectively applied at the workplace (Newstrom, 1986) \\
\hline 12. & $\begin{array}{l}\text { Variety of tech- } \\
\text { niques }\end{array}$ & The use of multiple learning and development techniques in the context of a PD trajectory (authors' definition) \\
\hline 13. & $\begin{array}{l}\text { Collegial and collec- } \\
\text { tive learning }\end{array}$ & $\begin{array}{l}\text { Learning activities in which participants construct knowledge, skills and/or attitudes in collaboration with fellows and/or col- } \\
\text { leagues (authors' definition) }\end{array}$ \\
\hline 14. & Networking & Learning activities/oucomes related to networking (authors' definition) \\
\hline
\end{tabular}

\section{References}

* Aas, M., 2016. Leaders as learners: Developing new leadership practices. Professional Development in Education 43 (3), $439-453$.

* Aas, M., Brandmo, C., 2016. Revisiting instructional and transformational leadership. Journal of Educational Administration 54 (1), $92-110$.

* Aas, M., Vavik, M., 2015. Group coaching: A new way of constructing leadership identity?. School Leadership \& Management 35 (3), $251-265$.

Bass, B., Avolio, B., 1994. Improving organisational effectiveness through transformational leadership. Sage, Thousand Oaks, CA.

Bass, B., Riggio, R., 2006. Transformational leadership. Mahwah, New Jersey: Erlbaum.

* Bossert, S., Dwyer, D., Rowan, B., Lee, G., 1982. The instructional management role of the principal. Educational Administration Quarterly 18 (3), $34-64$.

* Bush, T., 2013. Instructional leadership and leadership for learning: Global and South African perspectives. Education As Change 17 (1), 5-20.

Bush, T., Glover, D., 2003. School leadership: Concepts and evidence. National College for School Leadership, Oxford, United Kingdom, Retrieved from http://dera.ioe. ac.uk/5119/14/dok217-eng-School_Leadership_Concepts_and_Evidence_Redacted.pdf.

Cohen, L., Manion, L., Morrison, K., 2011. Research methods in education. Routledge, London/New York. 
* Cramp, A., 2016. Enhancing school leadership through an international study visit. Professional Development in Education 42 (5), 787-800.

Devos, G., Bouckenooghe, D., 2009. An exploratory study on principals' conceptions about their role as school leaders. Leadership and Policy in Schools 8 (2), $173-196$.

* Dös, I., Savas, A., 2015. Elementary school administrators and their roles in the context of effective schools. SAGE Open 5 (1)https://doi.org/10.1177/ 2158244014567400.

* Forde, McMahon, Gronn, 2013. Designing individualised leadership development programmes. School Leadership \& Management 33 (5), $440-456$.

* Fullan, M., 2006. The future of educational change: System thinkers in action. Journal of Educational Change 7 (3), $113-122$.

* Goldring, E., Preston, C., Huff, J., 2012. Conceptualizing and evaluating professional development for school leaders. Planning and Changing 43 (3/4), 223-242.

* Grissom, J., Loeb, S., 2011. Triangulating principal effectiveness. American Educational Research Journal 48 (5), $1091-1123$.

* Grissom, J., Loeb, S., Master, B., 2013. Effective instructional time use for school leaders: Longitudinal evidence from observations of principals. Educational Researcher $42(8), 433-444$.

* Grobler, B., 2013. The school principal as instructional leader: A structural equation model. Education As Change 17 (1), $177-199$.

* Gronn, P., 2002. Distributed leadership as a unit of analysis. The Leadership Quarterly 13 (4), 423-451.

* Gunter, H., Ribbins, P., 2002. Leadership studies in education: Towards a map of the field. Educational Management \& Administration 30 (4), 387-416.

* Hallinger, P., 2003. Leading educational change: Reflections on the practice of instructional and transformational leadership. Cambridge Journal of Education 33 (3), $329-352$.

* Hallinger, P., 2005. Instructional leadership and the school principal: A passing fancy that refuses to fade away. Leadership and Policy in Schools 4 (3), 221-239.

* Hallinger, P., 2011. Leadership for learning: Lessons from 40 years of empirical research. Journal of Educational Administration 49 (2), $125-142$.

Hallinger, P., 2013. A conceptual framework for systematic reviews of research in educational leadership and management. Journal of Educational Administration 51 (2), 126-149.

Hallinger, P., Bickman, L., Davis, K., 1996. School context, principal leadership and student reading achievement. The Elementary School Journal 96 (5), 527-549.

Hallinger, P., Heck, R., 1998. Exploring the principal's contribution to school effectiveness: 1980-1995. School Effectiveness and School Improvement 9 (2), $157-191$.

* Hallinger, P., Heck, R., 2010. Leadership for learning: Does collaborative leadership make a difference in school improvement?. Educational Management Administration \& Leadership 38 (6), 654-678.

* Hallinger, P., Huber, S., 2012. School leadership that makes a difference: International perspectives. School Effectiveness and School Improvement 23 (4), $359-367$.

* Harris, A., 2013. Distributed leadership: Friend or foe?. Educational Management Administration \& Leadership 41 (5), $545-554$.

* Harris, A., De Flaminis, J., 2016. Distributed leadership in practice: Evidence, misconceptions and possibilities. Management in Education 30 (4), 141-146.

* Heck, R., Hallinger, P., 2010. Testing a longitudinal model of distributed leadership effects on school improvement. The Leadership Quarterly 21 , 867-885.

* Heck, R., Marcoulides, G., 1996. School culture and performance: Testing the invariance of an organizational model. School Effectiveness and School Improvement 7 (1), 76-96.

* Helsing, D., Howell, A., Kegan, R., Lahey, L., 2008. Putting the development in professional development: Understanding and overturning educational leaders' immunities to change. Harvard Educational Review 78 (3), 437-465.

* Hitt, D., Tucker, P., 2016. Systematic review of key leader practices found to influence student achievement: A unified framework. Review of Educational Research 86 (2), 531-569.

Hobbs, G., 2016. Explaining social class inequalities in educational achievement in the UK: Quantifying the contribution of social class differences in school "effectiveness". Oxford Review of Education 42 (1), 16-35.

Hoy, W., Clover, S., 1986. Elementary school climate: A revision of the OCDQ. Educational Administration Quarterly 22 (1), 93-110.

Hoy, W., Miskel, C., 2013. Educational administration: Theory, research and practice. McGraw-Hill, New York.

* Huber, S., 2011. The impact of professional development: A theoretical model for empirical research, evaluation, planning and conducting training and development programmes. Professional Development in Education 37 (5), 837-853.

* Huber, S., 2013. Multiple learning approaches in the professional development of school leaders - theoretical perspectives and empirical findings on self-assessment and feedback. Educational Management Administration \& Leadership 41 (4), 527-540.

* Hulsbos, F., Evers, A., Kessels, J., 2016. Learn to lead: Mapping workplace learning of school leaders. Vocations and learning 9, $21-42$.

* Kondakci, Y., Sivri, H., 2014. Salient characteristics of high-performing Turkish elementary schools. Journal of Educational Administration 52 (2), $254-272$.

* Kruger, M., 2009. The big five of school leadership competences in The Netherlands. School Leadership \& Management 29 (2), $109-127$.

* Kurland, H., Peretz, H., Hertz-Lazarowitz, R., 2010. Leadership style and organizational learning: The mediate effect of school vision. Journal of Educational Administration 48 (1), 7-30.

* Land, D., 2002. Local school boards under review: Their role and effectiveness in relation to students' academic achievement. Review of Educational Research 72 (2), $229-278$.

* Leithwood, K., 1992. Transformational leadership: Where does it stand?. The Education Digest 58 (3), 17-21.

Leithwood, K., 2010. School leadership in the context of accountability policies. International Journal of Leadership in Education: Theory and Practice 4 (3), 304-326.

* Leithwood, K., Harris, A., Hopkins, D., 2008. Seven strong claims about successful school leadership. School Leadership \& Management 28 (1), $27-42$.

* Leithwood, K., Jantzi, D., 1999. Transformational school leadership effects: A replication. School Effectiveness and School Improvement 10 (4), $451-479$.

* Leithwood, K., Jantzi, D., 2005. A review of transformational school leadership research 1996-2005. Leadership and Policy in Schools 4 (3), $177-199$.

* Leithwood, K., Sleegers, P., 2006. Transformational school leadership: Introduction. School Effectiveness and School Improvement 17 (2), $143-144$.

* MacBeath, J., 2011. No lack of principles: Leadership development in England and Scotland. School Leadership \& Management 31 (2), $105-121$.

* Malone, B., Caddell, T., 2000. A crisis in leadership: Where are tomorrow's principals?. The Clearing House 73 (3), $162-164$.

* Marks, H., Printy, S., 2003. Principal leadership and school performance: An integration of transformational and instructional leadership. Educational Administration Quarterly 39 (3), 370-397.

* Marsh, S., 2012. Improving student learning in schools: Exploring leadership for learning as a community activity. Leading \& Managing 18 (1), 107-121.

* Marsh, S., 2015. A model for leadership that improves learning: New insights for schools and scholars. Leadership and Policy in Schools 14 (1), $67-103$.

* Marsh, S., Waniganayake, M., De Nobile, J., 2013. Leadership for learning as an intentional, community-wide activity: The importance of developing a shared language in schools. School Leadership \& Management 17 (1), 23-39.

* Mascall, B., Leithwood, K., Strauss, T., Sacks, R., 2008. The relationship between distributed leadership and teachers' academic optimism. Journal of Educational Administration 46 (2), 214-228.

* May, H., Huff, J., Goldring, E., 2012. A longitudinal study of principals' activities and student performance. School Effectiveness and School Improvement 23 (4), $417-439$.

Muijs, D., 2010. Leadership and organisational performance: From research to prescription. Leadership and organisational performance 25 (1), 45-60.

* Murphy, J., Elliott, S., Goldring, E., Porter, A., 2007. Leadership for learning: A research-based model and taxonomy of behaviours. School Leadership \& Management 27 (2), 179-201.

* Nedelcu, A., 2013. Transformational approach to school leadership: Contribution to continued improvement of education. Change And Leadership 17, 237-244.

Newstrom, J., 1986. Leveraging management development through the management of transfer. The Journal of Management Development 5 (5), $33-45$.

Nicolaidou, M., Petridou, A., 2011. Evaluation of CPD programmes: Challenges and implications for leader and leadership development. School Effectiveness and School Improvement $22(1), 51-85$.

* Odhiambo, G., Hii, A., 2006. Key stakeholders' perceptions of effective school leadership. Educational Management Administration \& Leadership 40 (2), $232-247$.

OECD, 2013. Education at a glance. OECD indicators, $440 \mathrm{pp}$.

* Parylo, O., Zepeda, S., 2014. Describing and 'effective' principal: Perceptions of the central office leaders. School Leadership \& Management 34 (5), $518-537$.

* Pashiardis, P., 1998. Researching the characteristics of effective primary school principals in Cyprus. Educational Management \& Administration 26 (2), 117-130.

* Penlington, C., Kington, A., Day, C., 2008. Leadership in improving schools: A qualitative perspective. School Leadership \& Management 28 (1), 65-82. 
* Peterson, K., 2002. The professional development of principals: Innovations and opportunities. Educational Administration Quarterly 38 (2), $213-232$.

* Piot, L., 2015. Andere tijden, andere leiders? Een beschrijving van leiderschapspraktijken op het bovenschoolse niveau. University Press Leuven, Leuven.

Popay, J., Roberts, H., Sowden, A., Petticrew, M., Arai, L., Rodgers, M., et al., 2006. Guidance on the conduct of narrative synthesis in systematic reviews: A product of the ESRC methods programme. Lancaster

* Reeves, J., Forde, C., Casteel, V., Lynas, R., 1998. Developing a model of practice: Designing a framework for the professional development of school leaders and managers. School Leadership \& Management 18 (2), 185-196.

* Robinson, V., 2008. Forging the links between distributed leadership and educational outcomes. Journal of Educational Administration 46 (2), 241-256.

* Robinson, V., 2010. From instructional leadership to leadership capabilities: Empirical findings and methodological challenges. Leadership and Policy in Schools 9 , 1-26.

* Robinson, V., Lloyd, K., Rowe, J., 2008. The impact of leadership on student outcomes: An analysis of the differential effects of leadership types. Educational Administration Quarterly 44 (5), 635-674.

* Ross, J., Gray, P., 2006. Transformational leadership and teacher commitment to organizational values: The mediating effects of collective teacher efficacy. School Effectiveness and School Improvement 17 (2), 179-199.

* Sahenk, S., 2010. Characteristics of the headmasters, teachers and students in an effective school. Social And Behavioural Sciences 2 (2), $4298-4304$.

* Salo, P., Nyland, J., Stjernstrøm, E., 2015. On the practice architectures of instructional leadership. Educational Management Administration \& Leadership 43 (4), 490-506.

Schein, E., 1996. Culture: The missing concept in organization studies. Administrative Science Quarterly 41 (2), $229-240$.

* Schneider, A., Burton, N., 2005. An ideal type? The characteristics of effective school principals perceived by aspiring principals both from within education and those from an alternate career path. Management in Education 19 (2), 6-9.

Schön, D., 1987. Educating the reflective practitioner: Toward a new design for teaching and learning in the professions. Wiley, Hoboken, NJ.

* Scott, S., 2010. Pragmatic leadership development in Canada: Investigating a mentoring approach. Professional Development in Education 36 (4), 563-579.

Segers, J., Vloeberghs, D., Henderickx, E., Inceoglu, I., 2011. Structuring and understanding the coaching industry: The coaching cube. The Academy of Management Learning and Education 10 (2), 204-221.

* Simkins, T., 2005. Leadership in education. Educational Management Administration \& Leadership 33 (1), 9-26.

* Simkins, T., 2012. Understanding school leadership and management development in England: Retrospect and prospect. Educational Management \& Leadership 40 (5), 621-640.

Spillane, J., 2006. Distributed leadership. Jossey-Bass, San Francisco.

* Stevenson, M., Hedberg, J., O'Sullivan, K., Howe, C., 2016. Leading learning: The role of school leaders in supporting continuous professional development. Professional Development in Education 42 (5), 818-835.

* Sun, J., Leithwood, K., 2012. Transformational school leadership effects on students achievement. Leadership and Policy in Schools 11 (4), $418-451$.

* Supovitz, J., Sirinides, P., May, H., 2010. How principals and peers influence teaching and learning. Educational Administration Quarterly 46 (1), 31-56.

* Thompson, G., Glasø, L., 2015. Situational leadership theory: A test from three perspectives. The Leadership \& Organization Development Journal 36 (5), 527-544.

* Townsend, T., Acker-Hocevar, M., Ballenger, J., Place, A., 2013. Voices from the field: What have we learned about instructional leaderhip?. Leadership and Policy in Schools 12 (1), 12-40.

Tynjälä, P., 2013. Towards a 3-P model of workplace learning: A literature review. Vocations and Learning 6 (1), 11-36.

Walia, S., Marks-Maran, D., 2014. Leadership development through action learning sets: An evaluation study. Nurse Education in Practice 14, $612-619$.

* van der Werf, G., 1997. Differences in school and instruction characteristics between high-, average- and low-effective schools. School Effectiveness and School Improvement 8 (4), 430-448.

Witziers, B., Bosker, R., Kruger, M., 2003. Educational leadership and student achievement: The elusive search for an association. Educational Administration Quarterly 39 (3), 398-425.

* Wright, L., Da Costa, J., 2016. Rethinking professional development for school leaders: Possibilities and tensions. Educational Administration and Foundations Journal 25 (1), 29-47.

Yukl, G., 2002. Leadership in organisations. Prentice Hall, Upper Saddle River.

Yukl, G., 2012. Effective leadership behavior: What we know and what questions need more attention. Academy of Management Perspectives 26 (4), $66-85$.

* Yu, H., Leithwood, K., Jantzi, D., 2002. The effects of transformational leadership on teachers' commitment to change in Hong Kong. Journal of Educational Administration 40 (4), 368-389.

* Zhang, W., Brundrett, M., 2010. School leaders' perspectives on leadership learning: The case for informal and experiential learning. Management in Education 24 (4), 154-158. 